University of Nebraska - Lincoln

DigitalCommons@University of Nebraska - Lincoln

NASA Publications

National Aeronautics and Space Administration

2010

Thermal expansion of vacuum plasma sprayed coatings

S.V. Raj

NASA Glenn Research Center, sai.v.raj@nasa.gov

A. Palczer

NASA Glenn Research Center

Follow this and additional works at: https://digitalcommons.unl.edu/nasapub

Part of the Physical Sciences and Mathematics Commons

Raj, S.V. and Palczer, A., "Thermal expansion of vacuum plasma sprayed coatings" (2010). NASA

Publications. 82.

https://digitalcommons.unl.edu/nasapub/82

This Article is brought to you for free and open access by the National Aeronautics and Space Administration at DigitalCommons@University of Nebraska - Lincoln. It has been accepted for inclusion in NASA Publications by an authorized administrator of DigitalCommons@University of Nebraska - Lincoln. 


\title{
Thermal expansion of vacuum plasma sprayed coatings
}

\author{
S.V. Raj*, A. Palczer \\ NASA Glenn Research Center, MS 106-5, 21000 Brookpark Road, Cleveland, OH 44135, United States
}

\section{A R T I C L E I N F O}

\section{Article history:}

Received 4 November 2009

Received in revised form

20 November 2009

Accepted 23 November 2009

\section{Keywords:}

Thermal expansion

Vacuum plasma sprayed coatings

Copper alloy coatings

$\mathrm{NiAl}$ coating

NiCrAlY coating

Launch vehicles

\section{A B S T R A C T}

Metallic $\mathrm{Cu}-8 \% \mathrm{Cr}, \mathrm{Cu}-26 \% \mathrm{Cr}, \mathrm{Cu}-8 \% \mathrm{Cr}-1 \% \mathrm{Al}$, NiAl and NiCrAlY monolithic coatings were fabricated by vacuum plasma spray deposition processes for thermal expansion property measurements between 293 and $1223 \mathrm{~K}$. The corrected thermal expansion, $\left(\Delta L / L_{0}\right)_{\text {thermal, }}$, varies with the absolute temperature, $T$, as

$$
\left(\frac{\Delta L}{L_{0}}\right)_{\text {thermal }}=A(T-293)^{3}+B(T-293)^{2}+C(T-293)+D
$$

where $A, B, C$ and $D$ are regression constants. Excellent reproducibility was observed for all of the coatings except for data obtained on the $\mathrm{Cu}-8 \% \mathrm{Cr}$ and $\mathrm{Cu}-26 \% \mathrm{Cr}$ coatings in the first heat-up cycle, which deviated from those determined in the subsequent cycles. This deviation is attributed to the presence of residual stresses developed during the spraying of the coatings, which are relieved after the first heat-up cycle. In the cases of $\mathrm{Cu}-8 \% \mathrm{Cr}$ and $\mathrm{NiAl}$, the thermal expansion data were observed to be reproducible for three specimens. The linear expansion data for $\mathrm{Cu}-8 \% \mathrm{Cr}$ and $\mathrm{Cu}-26 \% \mathrm{Cr}$ agree extremely well with rule of mixture (ROM) predictions. Comparison of the data for the $\mathrm{Cu}-8 \% \mathrm{Cr}$ coating with literature data for $\mathrm{Cr}$ and $\mathrm{Cu}$ revealed that the thermal expansion behavior of this alloy is determined by the $\mathrm{Cu}$-rich matrix. The data for $\mathrm{NiAl}$ and $\mathrm{NiCrAlY}$ are in excellent agreement with published results irrespective of composition and the methods used for processing the materials. The implications of these results on coating GRCop-84 copper alloy combustor liners for reusable launch vehicles are discussed.

Published by Elsevier B.V.

\section{Introduction}

Many engineering components experience temperature variations during service, which often require the availability of good quality data to ensure that they can be designed reliably and safely to meet the required design objectives. The necessity for generating high quality data is more critical for aerospace components especially those where two or more different materials are bonded to each other to fabricate components with optimized design properties. For example, differences between the thermophysical and mechanical properties of coating materials and the substrate can lead to the development of large residual stresses, which can either distort or debond the coating from the substrate during thermal cycling of a coated component during service.

The National Aeronautics and Space Administration (NASA) has been developing technologies for a new generation of advanced reusable launch vehicles (RLVs) in its efforts to increase its future heavy lift capacity in a more reliable and economical manner

\footnotetext{
* Corresponding author at: Materials \& Structures Division, NASA Glenn Research Center, MS 106-5, 21000 Brookpark Road, Cleveland, OH 44135, United States. Tel.: +1 216433 8195; fax: +1 2164335544 .

E-mail address: sai.v.raj@nasa.gov (S.V.Raj).
}

compared to the Space Shuttle. Combustion chamber liners in liquid hydrogen $\left(\mathrm{LH}_{2}\right)$ fueled-rocket engines experience extreme conditions due to a combination of environmental and thermomechanical effects. The combustion flame temperatures in the chamber interior are about $3600 \mathrm{~K}$ whereas the backside of the approximately $1 \mathrm{~mm}$ thick liner wall experiences cryogenic temperatures of $20 \mathrm{~K}$ [1-6]. Uncoated copper and its alloys have been used as combustor liner materials in these regenerative rocket engines because their high thermal conductivities enable efficient heat transfer from the combustion flame to preheat the cryogenic $\mathrm{LH}_{2}$ flowing in the cooling channels. However, uncoated copper alloy liners undergo environmental degradation due to a combination of the spallation of the locally formed copper oxide scales and "blanching", which consists of repeated oxidation of the copper matrix and subsequent reduction of the oxide scale [6].

The design of the next generation of RLVs calls for using GRCop$84(\mathrm{Cu}-8(\mathrm{at} . \%) \mathrm{Cr}-4 \% \mathrm{Nb})$ copper alloy liners due to its superior properties compared to conventional high conductivity copper alloys, such as NARloy-Z [7-9]. The application of protective coatings on GRCop-84 and other copper alloy substrates can minimize or eliminate many of the problems experienced by uncoated liners and significantly extend their operational lives in RLVs. This factor potentially translates to increased component reliability, shorter depot maintenance time and lower operational cost. In addition, the 

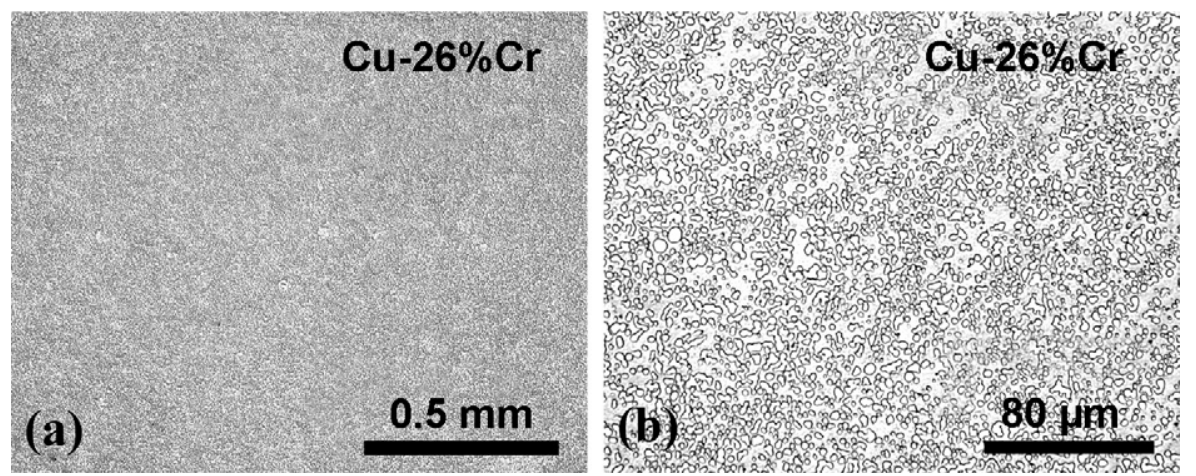

Fig. 1. (a) Low and (b) high magnification views of the optical microstructures of vacuum plasma sprayed $\mathrm{Cu}-26 \% \mathrm{Cr}$ monolithic coatings.

use of a suitable top coat to act as a thermal barrier $^{1}$ can allow the engine to run at higher temperatures thereby resulting in increased thermal efficiency. As a result, several types of ceramic $[1,5]$ and metallic [10-15] coatings have been advocated as protective coatings for copper alloy liners. However, the presence of a coating will significantly reduce the thermal conductivity of the liner compared to the uncoated copper alloys, which suggests that metallic coatings are preferred to ceramic coatings.

As mentioned above, the application of coatings on a substrate can result in the development of residual stresses whenever the coated component experiences variations in temperature. These temperature variations can occur during different stages of processing, such as when the sprayed component cools to ambient after vacuum plasma spraying as well as after hot isostatic pressing (HIP) of the component. Differential thermal expansion can also result in thermally induced residual stresses during temperature cycles in service. It is important to note that the surface temperature of the combustion liner is expected to increase from cryogenic temperatures to $800-1100 \mathrm{~K}$ within $3 \mathrm{~s}$ on starting the engine. As a result, an enormous amount of differential thermal strain can develop in the coated substrate and lead to coating spallation during the transient heat-up portion of the cycle. In order to predict the performance of these coatings in service, as well as to gain insights on the nature and magnitudes of these residual stresses, it is essential to conduct finite element analysis (FEA) to simulate the performance of coated liners in a realistic combustion environment. The reliability of these analyses requires the generation of high quality mechanical and thermophysical property data. Recently, it was demonstrated that $\mathrm{CuCrAl}$ and NiCrAlY coatings deposited either by the cold spray or the vacuum plasma spray techniques are potentially viable coatings for GRCop-84 combustion liners [14,15]. However, thermophysical data for these sprayed coatings are either limited or nonexistent in the temperature range of interest for use in RLVs. Although thermal conductivity data of vacuum plasma sprayed NiCrAlY alloys $[16,17]$ have been previously reported in the literature, it is important to note that these properties are sensitive to compositional and processing variables. Thus, it is essential that thermophysical data be generated on coatings sprayed under processing conditions and for compositions similar to those developed for spraying the GRCop-84 liners in order to ensure reliable design models to be developed.

The objective of this paper is to report the temperature dependence of thermal expansion for vacuum plasma sprayed coatings $\mathrm{Cu}-\mathrm{Cr}, \mathrm{CuCrAl}, \mathrm{NiAl}$ and NiCrAlY coating alloys between 293 and $1223 \mathrm{~K}$. The data are analyzed to obtain valuable insights on the

\footnotetext{
1 The term "thermal barrier" is used to signify that the coated copper liners are likely to possess lower thermal conductivity than uncoated copper alloys.
}

behavior of these alloys during heat-up and cool-down thermal cycles.

\section{Experimental procedures}

\subsection{Alloy composition and processing}

Gas atomized copper alloy powders were procured from Crucible Research, Inc., Pittsburgh, PA whereas the NiAl and NiCrAlY powders were obtained from Homogenous Metals, Inc., NY and Sultzer Metco, MI, respectively. The nominal compositions of the alloy powders were $\mathrm{Cu}-8(\mathrm{wt} . \%) \mathrm{Cr}$, $\mathrm{Cu}-26$ (wt.\%)Cr, $\mathrm{Cu}-8$ (wt.\%)Cr-1\%Al, $\mathrm{Ni}-31.5$ (wt.\%)Al (NiAl), $\mathrm{Ni}-17$ (wt.\%)Cr-6\%Al-0.5\%Y. Monolithic cylindrical coatings, typically $175-250 \mathrm{~mm}$ long and $19-25 \mathrm{~mm}$ thick, were fabricated by spraying the powders on rotating steel mandrels, approximately $25 \mathrm{~mm}$ in diameter, by the vacuum plasma spray (VPS) method. The $\mathrm{Cu}-8 \% \mathrm{Cr}, \mathrm{Cu}-8 \% \mathrm{Cr}-1 \% \mathrm{Al}, \mathrm{NiAl}$ and NiCrAlY coatings were deposited by the vacuum plasma spray method at Plasma Processes, Inc., Huntsville, AL. The coated mandrels were hot isostatically pressed (HIP) between 1073 and $1273 \mathrm{~K}$ under argon gas pressures varying between 100 and $210 \mathrm{MPa}$ for times varying between 1 and $4 \mathrm{~h}$.

\subsection{Thermal expansion measurements}

Specimens were machined from the HIPed cylinders by electrodischarge machining (EDM). The specimen dimensions for thermal expansion measurements were $25.4 \mathrm{~mm}$ long and $6.35 \mathrm{~mm}$ in diameter for all coatings except for the $\mathrm{Cu}-8 \mathrm{Cr}-1 \mathrm{Al}$ alloy specimens, which were $12.7 \mathrm{~mm}$ long and $6.35 \mathrm{~mm}$ in diameter. The thermal expansion of the specimens was measured between 293 and $1223 \mathrm{~K}$ using a NETZSCH Dilatometer Model DIL 402C, which uses a single head design and high purity alumina as a calibration standard. Measurements were made over three heat-cool cycles to minimize the effects of compositional, microstructural and processing inhomogeneities on the data, verify their reproducibility, and statistically average the regression coefficients. The specimen was placed in a sample holder and aligned with a single push-rod with an applied constant load of $0.2 \mathrm{~N}$. The specimens were heated from 293 to $1223 \mathrm{~K}$ at $10 \mathrm{~K} / \mathrm{min}$. in a He atmosphere flowing at $60 \mathrm{cc} / \mathrm{min}$ in the first cycle and furnace cooled to $373 \mathrm{~K}$ in the first cool-down cycle. Subsequent cycles consisted of heating and cooling between 373 and $1223 \mathrm{~K}$. The length changes were recorded by a computerized data acquisition system. The experimental strain, $\Delta L / L_{0}$, where $\Delta L$ is the differential change in length, $L-L_{0}$, and $L_{0}$ is the original length of the specimen at room temperature, were measured. Specimen-to-specimen reproducibility measurements were made on three different specimens in the cases of $\mathrm{Cu}-8 \% \mathrm{Cr}$ and $\mathrm{NiAl}$. 

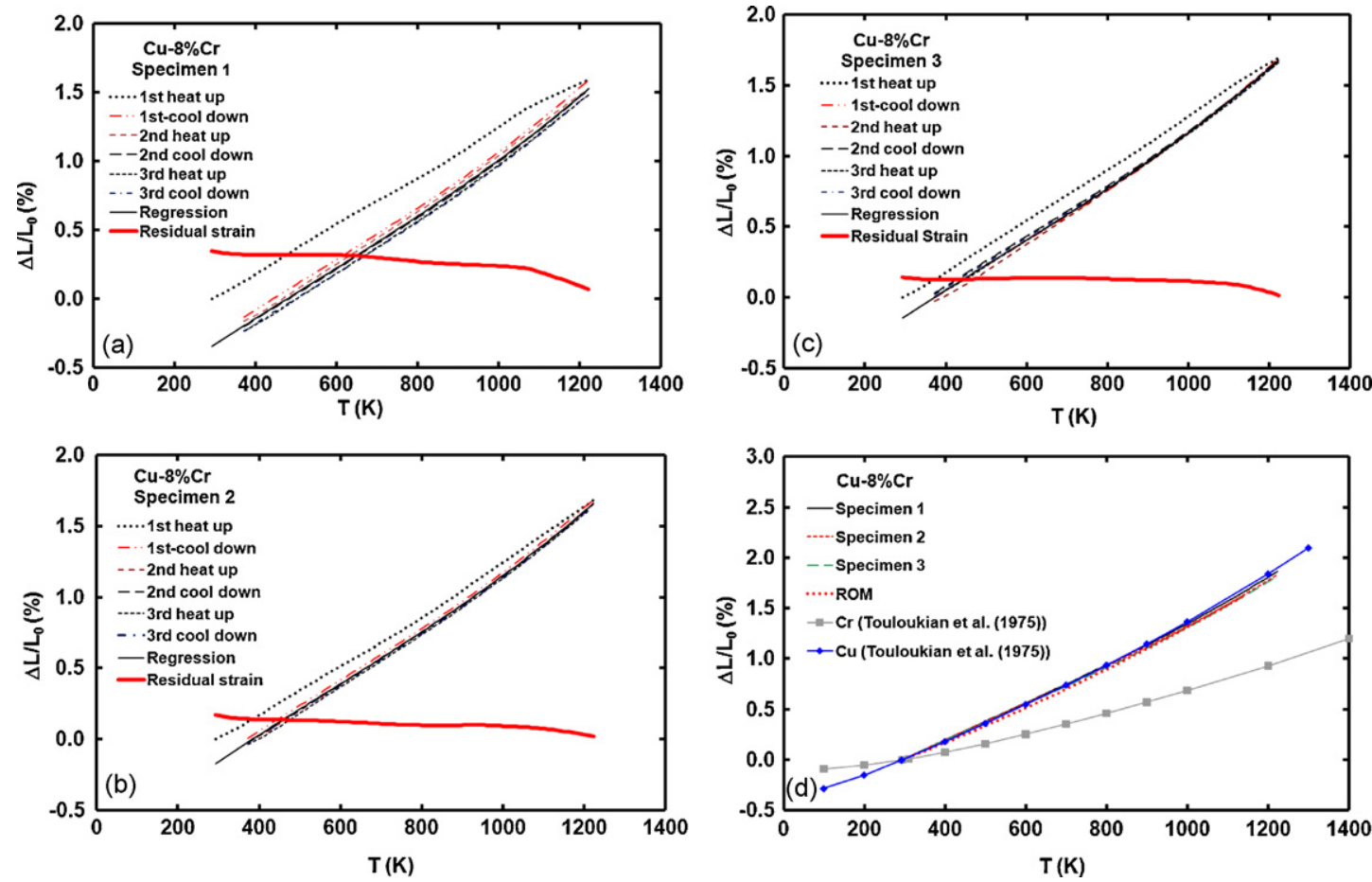

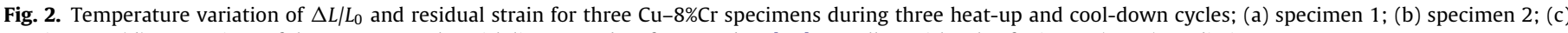
specimen 3; (d) comparison of the present results with literature data for $\mathrm{Cr}$ and $\mathrm{Cu}$ [20] as well as with rule of mixture (ROM) predictions.
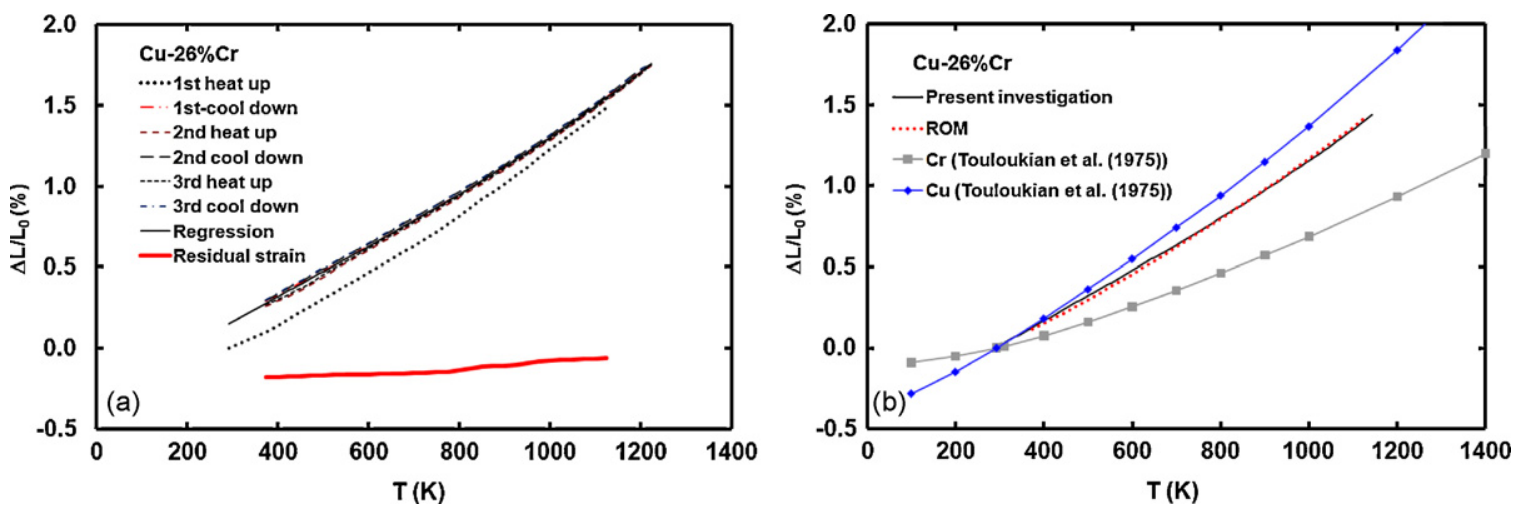

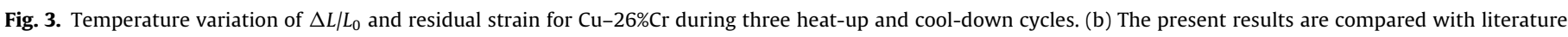
data for $\mathrm{Cr}$ and $\mathrm{Cu}[20]$ as well as with rule of mixture (ROM) predictions.

\section{Results and discussion}

\subsection{Microstructures}

The microstructures of the monolithic coatings were nearly fully dense with little visible porosity under an optical microscope. The $\mathrm{Cu}-26 \% \mathrm{Cr}$ (Fig. 1(a)) coatings revealed second phase $\alpha-\mathrm{Cr}$ particles in the matrix at higher magnifications (Fig. 1(b)). The NiCrAlY coating was also nearly fully dense although fine grain boundary porosity was observed at the higher magnifications $(>400 \times)$. The $\mathrm{Cu}-8 \% \mathrm{Cr}$ coating was nearly fully dense with very little porosity visible in the microstructures. Similar nearly full dense microstructures were observed in the $\mathrm{NiAl}$ and $\mathrm{Cu}-8 \% \mathrm{Cr}-1 \% \mathrm{Al}$ coatings.

\subsection{Thermal expansion}

\subsection{1. $\mathrm{Cu}-8 \% \mathrm{Cr}$}

Fig. 2(a-c) compares the variation of $\Delta L / L_{0}$ with $T$, during three heat-up and cool-down cycles for three $\mathrm{Cu}-8 \% \mathrm{Cr}$ specimens. For all three specimens, the magnitudes of thermal expansion in the first heat-up cycle were higher than those recorded in subsequent heat-up and cool-down cycles. In contrast, the thermal expan-

Table 1

Values of the regression constants for VPS $\mathrm{Cu}-8 \% \mathrm{Cr}$ coating.

\begin{tabular}{|c|c|c|c|c|c|c|}
\hline Specimen no. & Cycle description & $A\left(\mathrm{~K}^{-3}\right)$ & $B\left(\mathrm{~K}^{-2}\right)$ & $C\left(\mathrm{~K}^{-1}\right)$ & $D$ & $R_{\mathrm{d}}^{2}$ \\
\hline 1 & 1st cool-down to 3rd cool-down & $4.7 \times 10^{-10}$ & $-3.3 \times 10^{-7}$ & $1.9 \times 10^{-3}$ & $-3.4 \times 10^{-1}$ & 0.994 \\
\hline 2 & 1st cool-down to 3rd cool-down & $5.3 \times 10^{-10}$ & $-4.1 \times 10^{-7}$ & $1.9 \times 10^{-3}$ & $-1.7 \times 10^{-1}$ & 0.999 \\
\hline 3 & 1st cool-down to 3rd cool-down & $5.2 \times 10^{-10}$ & $-3.8 \times 10^{-7}$ & $1.9 \times 10^{-3}$ & $-1.4 \times 10^{-1}$ & 0.999 \\
\hline Combined data for specimens $1-3$ & 1st cool-down to 3 rd cool-down & $5.1 \times 10^{-10}$ & $-3.7 \times 10^{-7}$ & $1.9 \times 10^{-3}$ & $-2.2 \times 10^{-1}$ & 0.972 \\
\hline
\end{tabular}



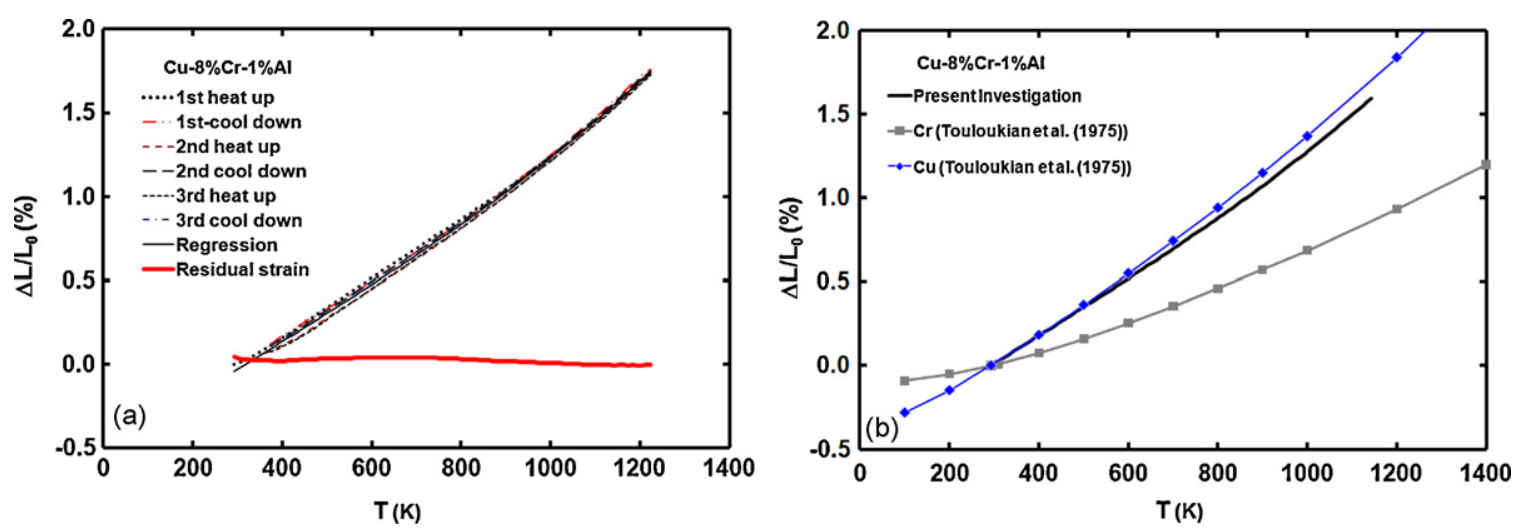

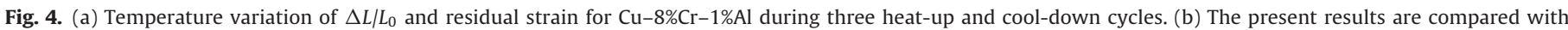
literature data for $\mathrm{Cr}$ and $\mathrm{Cu}[20]$.

Table 2

Values of the fitting constants for VPS $\mathrm{Cu}-26 \% \mathrm{Cr}$ coating.

\begin{tabular}{|c|c|c|c|c|c|c|}
\hline Specimen no. & Cycle description & $A\left(\mathrm{~K}^{-3}\right)$ & $B\left(\mathrm{~K}^{-2}\right)$ & $C\left(\mathrm{~K}^{-1}\right)$ & $D$ & $R_{\mathrm{d}}^{2}$ \\
\hline 1 & 1st cool-down to 3rd cool-down & $3.8 \times 10^{-10}$ & $-1.9 \times 10^{-7}$ & $1.6 \times 10^{-3}$ & $1.5 \times 10^{-1}$ & 0.999 \\
\hline
\end{tabular}

Table 3

Values of the fitting constants for VPS $\mathrm{Cu}-8 \% \mathrm{Cr}-1 \% \mathrm{Al}$ coating.

\begin{tabular}{|c|c|c|c|c|c|c|}
\hline Specimen no. & Cycle description & $A\left(\mathrm{~K}^{-3}\right)$ & $B\left(\mathrm{~K}^{-2}\right)$ & $C\left(\mathrm{~K}^{-1}\right)$ & $D$ & $R_{\mathrm{d}}^{2}$ \\
\hline 1 & 1st cool-down to 3rd cool-down & $4.3 \times 10^{-10}$ & $-1.6 \times 10^{-7}$ & $1.7 \times 10^{-3}$ & $-4.4 \times 10^{-2}$ & 0.998 \\
\hline
\end{tabular}

sion was nominally identical from the first to the third cool-down cycle although the data for specimen 3 exhibited slightly more scatter (Fig. 2(c)). This observed difference in the magnitudes of $\Delta L / L_{0}$ between the first and subsequent cycles is most likely due to the presence of multiaxial residual stresses initially developed in the splat-cooled grains of the coating microstructure during processing. The nature and calculation of these residual stresses are fairly involved [18-20]. As a result, the measured values of $\left(\Delta L / L_{0}\right)_{\text {first cycle }}$ for the first heat-up cycle consist of a uniaxial residual strain component and a thermal strain component. Thus:

$$
\left(\frac{\Delta L}{L_{0}}\right)_{\text {first cycle }}=\left(\frac{\Delta L}{L_{0}}\right)_{\text {thermal }}+\left(\frac{\Delta L}{L_{0}}\right)_{\text {residual }}
$$

where $\left(\Delta L / L_{0}\right)_{\text {thermal }}$ and $\left(\Delta L / L_{0}\right)_{\text {residual }}$ are the thermal and residual strains, respectively. Since the temperature dependence of $\Delta L / L_{0}$ for the first to the third cool-down cycles is nearly identical (Fig. 2(a-c)), it is reasonable to assume that its magnitude can be determined from these data. Subsequently, the temperature dependence of $\left(\Delta L / L_{0}\right)_{\text {residual }}$ can be determined.

The temperature dependence of $\left(\Delta L / L_{0}\right)_{\text {thermal }}$ could be well represented by [21]:

$$
\left(\frac{\Delta L}{L_{0}}\right)_{\text {thermal }}=A(T-293)^{3}+B(T-293)^{2}+C(T-293)+D
$$

where $A, B, C$ and $D$ are constants. Table 1 shows the values of these constants determined from a polynomial regression of the experimental data for the three specimens and the corresponding coefficients of determination, $R_{\mathrm{d}}{ }^{2}$, for each thermal cycle. The magnitudes of the constants determined for the three specimens are similar thereby confirming the reproducibility in the data. The values of $\left(\Delta L / L_{0}\right)_{\text {thermal }}$ were subtracted from the measured values of $\left(\Delta L / L_{0}\right)_{\text {first cycle }}$ to determine the temperature dependence of $\left(\Delta L / L_{0}\right)_{\text {residual }}$ (Figs. $2(\mathrm{a}-\mathrm{c})$ ).
Fig. 2(d) compares the regressed curves ${ }^{2}$ for the three specimens based on the constants given in Table 1 with literature data for $\mathrm{Cr}$ [21] and $\mathrm{Cu}$ [21]. The regressed values for the three specimens are in excellent agreement and closely follow the trend exhibited by $\mathrm{Cu}$ [21] while deviating considerably from the thermal expansion data for $\mathrm{Cr}$ [21]. This is not surprising since $\mathrm{Cr}$ has low solubility in $\mathrm{Cu}$ [22] so that for practical purposes the thermal expansion of $\mathrm{Cu}-8 \% \mathrm{Cr}$ should be similar to that of $\mathrm{Cu}$ given the relatively low volume fraction, $V_{\mathrm{f}}$, of the $\alpha-\mathrm{Cr}$ particles $\left(V_{\mathrm{f}} \sim 9 \%\right)$. The excellent agreement between the predicted thermal expansion for the alloy based on a rule of mixtures (ROM) model with the experimental data provides additional confirmation (Fig. 2(d)).

\subsection{2. $\mathrm{Cu}-26 \% \mathrm{Cr}$}

Fig. 3(a) shows the temperature dependence of the thermal expansion for $\mathrm{Cu}-26 \% \mathrm{Cr}$. In contrast to $\mathrm{Cu}-8 \% \mathrm{Cr}$ (Fig. 2), the values of $\Delta L / L_{0}$ for the first heat-up cycle are lower than the measured values for the first cool-down and other subsequent thermal cycles. Fig. 3(b) compares the regressed values after correcting for the room temperature residual strain offset with the data for $\mathrm{Cr}$ and $\mathrm{Cu}$ [21], as well as the predicted values from a ROM model $\left(V_{\mathrm{f}} \sim 30 \%\right)$. Equation (2) is an excellent fit to the experimental data, where the regression parameters and values of $R_{\mathrm{d}}{ }^{2}$, are given in Table 2. Once again, the differences between the first heat-up cycle and the subsequent thermal cycles are attributed to residual stresses developed in the coating during processing. The corresponding temperature dependence of residual strain is also shown in Fig. 3(a). The magnitudes of the uniaxial residual strain are compressive in $\mathrm{Cu}-26 \% \mathrm{Cr}$ compared to the tensile strains observed in $\mathrm{Cu}-8 \% \mathrm{Cr}$ (Fig. 2(a-c)), which suggests that there is no simple relationship between the development of residual stresses during processing and the $\mathrm{Cr}$ con-

\footnotetext{
2 The regressed curves were corrected for the residual strain offset at room temperature to ensure that $\Delta L / L_{0}$ values are zero at room temperature. Similar corrections were made for the data for the other coating alloys.
} 

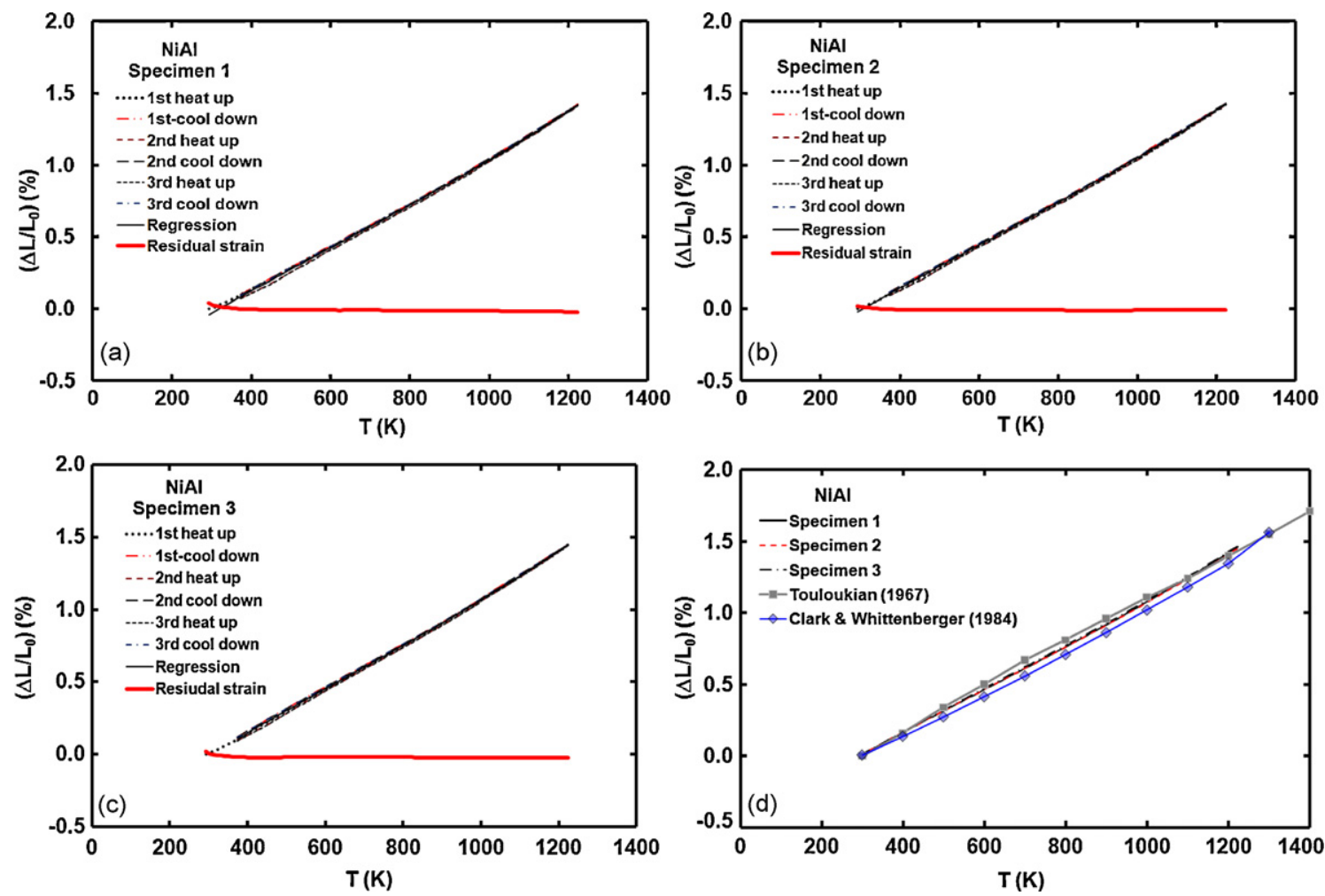

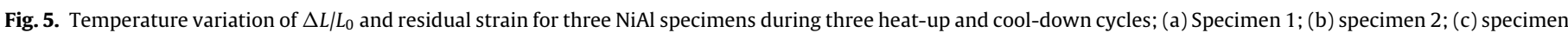
3 ; (d) comparison of the present results with literature data for $\mathrm{NiAl}[24,25]$.

tent of the alloys. A comparison of Figs. 2(d) and 3(b) reveals that the thermal expansion of $\mathrm{Cu}-\mathrm{Cr}$ alloy coatings decrease with increasing $\mathrm{Cr}$ content consistent with the ROM model.

\subsection{3. $\mathrm{Cu}-8 \% \mathrm{Cr}-1 \% \mathrm{Al}$}

While $\mathrm{Cr}$ solubility in the $\mathrm{Cu}$ matrix is negligible in the $\mathrm{Cu}-\mathrm{Cr}$ alloys [22], Al is mainly in solid solution in the $\mathrm{Cu}$ matrix in the $\mathrm{Cu}-\mathrm{Cr}-\mathrm{Al}$ system [23,24]. Fig. 4(a) shows the temperature dependence of $\Delta L / L_{0}$ for $\mathrm{Cu}-8 \% \mathrm{Cr}-1 \% \mathrm{Al}$ for the first heat-up and subsequent thermal cycles, respectively. Fig. 4(b) compares the present results with literature data for $\mathrm{Cr}$ and $\mathrm{Cu}$ [21]. The regression parameters using Eq. (2) and the corresponding $R_{\mathrm{d}}{ }^{2}$ are given in Table 3. The thermal expansion values in the first heat-up cycle are almost identical to those measured in the subsequent thermal cycles indicating that the residual strain is negligible. An examination of Fig. 4(b) shows that the thermal expansion of $\mathrm{Cu}-8 \% \mathrm{Cr}-1 \% \mathrm{Al}$ is slightly lower than that for $\mathrm{Cu}$ and $\mathrm{Cu}-8 \% \mathrm{Cr}$ (Fig. 2(d)).

\subsubsection{NiAl}

Fig. 5(a-c) shows the temperature dependence of the thermal expansion for three $\mathrm{NiAl}$ specimens. The magnitudes of $\Delta L / L_{0}$ in the first heat-up cycle are nearly identical to those determined in the subsequent thermal cycles similar to the observations on $\mathrm{Cu}-8 \% \mathrm{Cr}-1 \% \mathrm{Al}$ (Fig. 4(a)) coatings. Table 4 gives the corresponding regression parameters in Eq. (2) and values of $R_{\mathrm{d}}^{2}$ for the three NiAl specimens. These constants are in excellent agreement thereby suggesting that the specimen-to-specimen variation is negligible (Fig. 5(d)). There are no significant differences between the values of $\Delta L / L_{0}$ measured during the first heat-up cycle and the other subsequent cool-down and heat-up cycles corresponding to negligible residual strains. Literature data on hot-pressed NiAl [25] and hot-extruded NiAl [26] are shown for comparison in Fig. 5(d). The present data are in excellent agreement with the literature data $[25,26]$, which suggests that the temperature dependence of thermal expansion of NiAl is not significantly influenced by the processing method.

\subsubsection{NiCrAlY}

Fig. 6 shows the temperature dependence of $\Delta L / L_{0}$ for the $\mathrm{Ni}-17 \% \mathrm{Cr}-6 \% \mathrm{Al}-0.5 \% \mathrm{Y}$ coating and compares it with published data on $\mathrm{Ni}-20 \% \mathrm{Cr}-11 \% \mathrm{Al}-0.5 \% \mathrm{Y}$ [27]. Table 5 gives the regression parameters determined from the first to the third cool-down cycle. Once again, the residual strains are negligible as the values of $\Delta L / L_{0}$ for all the heat-up and cool-down cycles are similar within the limits of experimental scatter. As shown in Fig. 6, the thermal expansion of $\mathrm{Ni}-17 \% \mathrm{Cr}-6 \% \mathrm{Al}-0.5 \% \mathrm{Y}$ is slightly larger than $\mathrm{Ni}-20 \% \mathrm{Cr}-11 \% \mathrm{Al}-0.5 \% \mathrm{Y}$ [27], where the deviation between the two sets of data increases with increasing temperature. Despite the relatively large compositional differences between the two coating

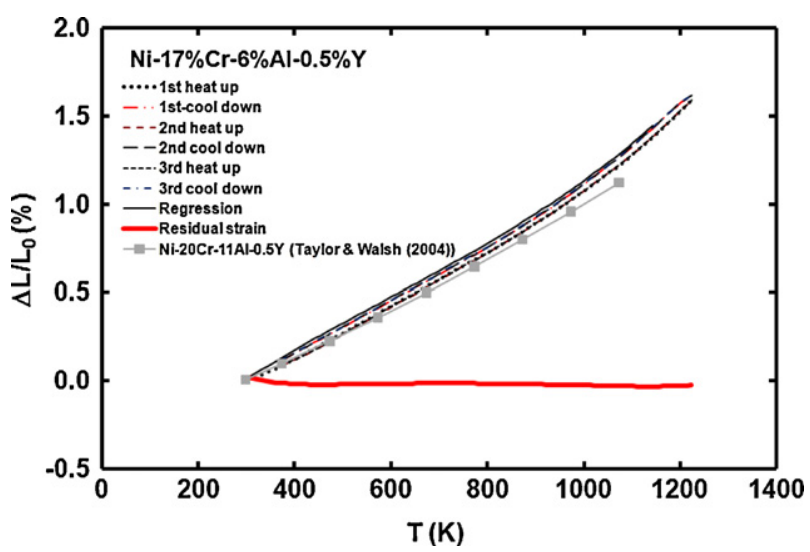

Fig. 6. Temperature variation of $\Delta L / L_{0}$ and residual strain for $\mathrm{Ni}-17 \% \mathrm{Cr}-6 \% \mathrm{Al}-0.5 \% \mathrm{Y}$ during three heat-up-cool-down cycles. The present results are compared with the predicted results for $\mathrm{Ni}-20 \% \mathrm{Cr}-11 \% \mathrm{Al}-0.5 \% \mathrm{Y}[26]$. 
Table 4

Values of the regression constants for VPS NiAl coatings.

\begin{tabular}{|c|c|c|c|c|c|c|}
\hline Specimen no. & Cycle description & $A\left(\mathrm{~K}^{-3}\right)$ & $B\left(\mathrm{~K}^{-2}\right)$ & $C\left(\mathrm{~K}^{-1}\right)$ & $D$ & $R_{\mathrm{d}}^{2}$ \\
\hline 1 & 1st cool-down to 3rd cool-down & $3.1 \times 10^{-10}$ & $-2.9 \times 10^{-7}$ & $1.6 \times 10^{-3}$ & $-4.0 \times 10^{-2}$ & 0.999 \\
\hline 2 & 1st cool-down to 3rd cool-down & $3.0 \times 10^{-10}$ & $-3.0 \times 10^{-7}$ & $1.6 \times 10^{-3}$ & $-2.1 \times 10^{-2}$ & 0.999 \\
\hline 3 & 1st cool-down to 3rd cool-down & $3.1 \times 10^{-10}$ & $-3.2 \times 10^{-7}$ & $1.6 \times 10^{-3}$ & $-2.1 \times 10^{-2}$ & 0.999 \\
\hline Combined data for specimens $1-3$ & 1st cool-down to 3rd cool-down & $3.1 \times 10^{-10}$ & $-3.0 \times 10^{-7}$ & $1.6 \times 10^{-3}$ & $-2.7 \times 10^{-2}$ & 0.998 \\
\hline
\end{tabular}

Table 5

Values of the fitting constants for VPS Ni-17\% Cr-6\% Al-0.5\%Y coating.

\begin{tabular}{|c|c|c|c|c|c|c|}
\hline Specimen no. & Cycle description & $A\left(\mathrm{~K}^{-3}\right)$ & $B\left(\mathrm{~K}^{-2}\right)$ & $C\left(\mathrm{~K}^{-1}\right)$ & $D$ & $R_{\mathrm{d}}^{2}$ \\
\hline 1 & 1st cool-down to 3rd cool-down & $1.0 \times 10^{-9}$ & $-8.6 \times 10^{-7}$ & $1.7 \times 10^{-3}$ & $-3.4 \times 10^{-2}$ & 0.998 \\
\hline
\end{tabular}

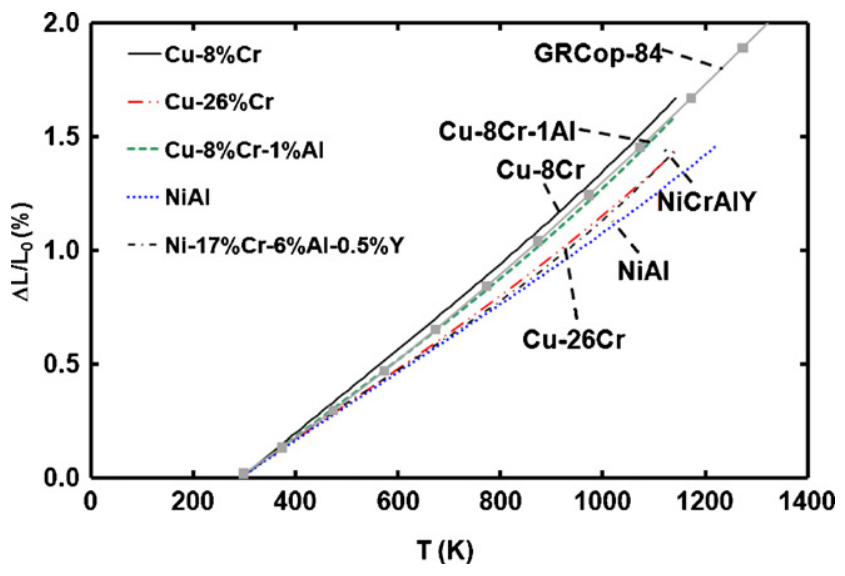

Fig. 7. Comparative plot showing the variation of $\Delta L / L_{0}$ with absolute temperature for VPS $\mathrm{Cu}-8 \% \mathrm{Cr}, \mathrm{Cu}-26 \% \mathrm{Cr}, \mathrm{Cu}-8 \% \mathrm{Cr}-1 \% \mathrm{Al}, \mathrm{NiAl}$ and $\mathrm{Ni}-17 \% \mathrm{Cr}-6 \% \mathrm{Al}-0.5 \% \mathrm{Y}$ monolithic coatings. The data for GRCop-84 [7] are also shown for comparison.

alloys, the differences in the values of $\Delta L / L_{0}$ are sufficiently small to conclude that other NiCrAlY coatings with similar compositions would have comparable $\Delta L / L_{0}$ values.

\subsection{Implications for coating GRCop-84 combustion liners}

$\mathrm{NiCrAlY}$ and $\mathrm{NiAl}$ have been proposed as protective top coats for GRCop-84 rocket engine combustion liners for reusable launch vehicles using $\mathrm{Cu}-\mathrm{Cr}$ or $\mathrm{Cu}-\mathrm{Cr}-\mathrm{Al}$ bond coats [14]. Fig. 7 compares the thermal expansions for $\mathrm{Cu}-8 \% \mathrm{Cr}, \mathrm{Cu}-26 \% \mathrm{Cr}, \mathrm{Cu}-8 \% \mathrm{Cr}-1 \% \mathrm{Al}$, $\mathrm{NiAl}, \mathrm{NiCrAlY}$ and GRCop-84 [7]. The differences in the magnitudes of thermal expansions between $\mathrm{Cu}-8 \% \mathrm{Cr}$ on one hand, and $\mathrm{NiAl}$ and $\mathrm{NiCrAlY}$ on the other are relatively large, and increase with increasing temperature. These observations suggest that using $\mathrm{Cu}-8 \% \mathrm{Cr}$ as a bond coat with either NiAl or NiCrAlY as a top coat on a GRCop84 substrate is likely to result in the development of large residual thermal stresses when the rocket engine is first fired.

On close examination, it is evident that the thermal expansion characteristics of NiCrAlY and $\mathrm{Cu}-26 \% \mathrm{Cr}$ are fairly similar over a wide temperature range, which suggests that the thermal residual stresses would be small when NiCrAlY is used as a top coat with a $\mathrm{Cu}-26 \% \mathrm{Cr}$ bond coat. $^{3}$ In contrast, the differences in the thermal expansions between a $\mathrm{NiAl}$ top coat and a $\mathrm{Cu}-26 \% \mathrm{Cr}$ bond coat increase with increasing temperature thereby limiting the use of $\mathrm{NiAl}$ as a top coat due to an increased probability of coating spallation at higher temperatures. Despite the similarities in the

\footnotetext{
${ }^{3}$ It is important to note that in practice, the $\mathrm{Cu}-26 \% \mathrm{Cr}$ coating layer would have residual stresses due to spraying on the substrate prior to the deposition of NiCrAlY top layer, which complicates modeling the residual stresses in a relatively simple manner.
}

magnitudes of the thermal expansions of $\mathrm{Cu}-26 \% \mathrm{Cr}$ and NiCrAlY, it is important to note that the thermal expansion between the GRCop-84 and $\mathrm{Cu}-26 \% \mathrm{Cr}$ increases with increasing temperature. Thus, there is a danger that residual stresses developed at the $\mathrm{Cu}-26 \% \mathrm{Cr} / \mathrm{GRCop}-84$ interface could weaken the strength of the bond and lead to coating spallation when NiCrAlY and $\mathrm{Cu}-26 \% \mathrm{Cr}$ are used as top and bond coats on a GRCop-84 liner.

Fig. 7 shows that the thermal expansion characteristics of the $\mathrm{Cu}-8 \% \mathrm{Cr}-1 \% \mathrm{Al}$ coating are almost identical to that for GRCop84. The addition of $1 \% \mathrm{Al}$ to $\mathrm{Cu}-8 \% \mathrm{Cr}$ results in a very close match in the thermal expansions of $\mathrm{Cu}-8 \% \mathrm{Cr}-1 \% \mathrm{Al}$ and GRCop- 84 . Thus, relatively low residual stresses are likely to develop at the $\mathrm{Cu}-8 \% \mathrm{Cr}-1 \% \mathrm{Al} / \mathrm{GRCop}-84$ interface. However, the differences in the thermal expansions between $\mathrm{Cu}-8 \% \mathrm{Cr}-1 \% \mathrm{Al}$ and $\mathrm{NiAl}$ and $\mathrm{NiCrAlY}$ are much larger especially at the higher temperatures, which is likely to lead to the development of significant residual stresses at the bond coat-top coat interfaces.

It is important to note that the magnitude of residual stresses and their effects on coating spallation are determined only partially by differences in thermal expansion between the top coat, bond coat and the GRCop-84 substrate. Other factors, such as elastic modulus, ultimate and yield stress, impurities and microstructures, also influence the magnitudes of the residual stresses and the probability of coating spallation so that precise determination of the local residual stress distribution is often difficult to ascertain. Thermal cycling tests conducted on a NiCrAlY-coated GRCop-84 water-cooled specimen using either a $\mathrm{Cu}-8 \% \mathrm{Cr}$ or a $\mathrm{Cu}-8 \% \mathrm{Cr}-1 \% \mathrm{Al}$ bond coat under a high heat flux $\mathrm{H}_{2} / \mathrm{O}_{2}$ combustion flame did not show any evidence of coating spallation after 40 cycles [14]. Although the differences in thermal expansions between either the $\mathrm{Cu}-8 \% \mathrm{Cr}$ or a $\mathrm{Cu}-8 \% \mathrm{Cr}-1 \% \mathrm{Al}$ alloy bond coat and the NiCrAlY alloy top coat increases with increasing temperature, heat transfer analyses of heat fluxes similar to those in a rocket engine reveal that for a top coat thickness of about $0.1 \mathrm{~mm}$, the interface temperatures are likely to be less than $625 \mathrm{~K} \mathrm{[14].}$ Indeed, finite element analyses of the out-of-plane stresses developed during these thermal cycles reveal that their magnitudes are identical under these high heat flux conditions for both $\mathrm{Cu}-8 \% \mathrm{Cr}$ and $\mathrm{Cu}-8 \% \mathrm{Cr}-1 \% \mathrm{Al}$ bond coats deposited on GRCop-84 substrates using NiCrAlY top coats [14]. In this case, the out-of-plane stress at the NiCrAlY/bond coat interface increased from -580 to $-150 \mathrm{MPa}$ in traversing from the top to the bond coat. The fact that coating spallation did not occur in these high heat flux thermal cycling experiments [14] despite the differences in magnitudes of $\Delta L / L_{0}$ for $\mathrm{Cu}-8 \% \mathrm{Cr}, \mathrm{Cu}-8 \% \mathrm{Cr}-1 \% \mathrm{Al}$ and NiCrAlY (Fig. 7) suggests that these residual stresses are accommodated by the plasticity of the bond coats.

Although Fig. 7 suggests that $\mathrm{Cu}-26 \% \mathrm{Cr}$ could be used as suitable bond coat for NiCrAlY top coat, it is important to note that experimental observations revealed that $\mathrm{Cu}-26 \% \mathrm{Cr}$ top coats either spalled in cyclic oxidation tests [28] or blistered under high heat flux conditions [14]. Unlike the more ductile NiCrAlY, 
the brittleness of a NiAl top coat may result in its spallation due to its inability to accommodate any thermal strain mismatch with the $\mathrm{Cu}-8 \% \mathrm{Cr}-1 \% \mathrm{Al}$ bond coat. Therefore, it is concluded that $\mathrm{Cu}-8 \% \mathrm{Cr}-1 \% \mathrm{Al}$ and $\mathrm{NiCrAlY}$ are likely to be the most suitable protective bond and top coat combination for GRCop-84.

\section{Summary and conclusions}

The temperature dependence of the thermal expansion, $\Delta L / L_{0}$, of vacuum plasma sprayed $\mathrm{Cu}-8 \% \mathrm{Cr}, \mathrm{Cu}-26 \% \mathrm{Cr}, \mathrm{Cu}-8 \% \mathrm{Cr}-1 \% \mathrm{Al}$, $\mathrm{NiAl}$ and $\mathrm{Ni}-17 \% \mathrm{Cr}-6 \% \mathrm{Cr}-0.5 \% \mathrm{Al}$ monolithic coatings between 300 and $1223 \mathrm{~K}$ are reported. Excellent specimen-to-specimen and cycle-to-cycle reproducibility were observed for all the coatings except during the first heat-up cycle for which the thermal expansion was different than those in the subsequent cycles. The observed behavior could be well represented by the equation: $\left(\Delta L / L_{0}\right)_{\text {thermal }}=A(T-293)^{3}+B(T-293)^{2}+C(T-293)+D$. Comparison of the data for $\mathrm{Cu}-8 \% \mathrm{Cr}$ and $\mathrm{Cu}-26 \% \mathrm{Cr}$ alloy coatings with literature data for $\mathrm{Cr}$ and $\mathrm{Cu}$, as well as rule of mixture predictions, revealed that the thermal expansion behaviors of these alloys are determined primarily by the $\mathrm{Cu}$-rich matrix. The data for $\mathrm{NiAl}$ are in excellent agreement with published results irrespective of the methods used for processing the materials. It is concluded that the $\mathrm{Cu}-8 \% \mathrm{Cr}-1 \% \mathrm{Al}$ coating would be the most suitable bond coat for GRCop-84 with NiCrAlY being the most suitable top coat.

\section{Acknowledgements}

The authors thank Dr. David Ellis for his comments and suggestions, and Mr. George Thom, Plasma Processes, Inc., Huntsville, AL, for vacuum plasma spraying the specimens.

\section{References}

[1] R.J. Quentmeyer, Experimental Fatigue Life Investigation of Cylindrical Thrust Chambers, NASA TM X-73665, Lewis Research Center, OH, 1977.

[2] D.K. Huzel, D.H. Huang, in: A.R. Seebass (Ed.), Modern Engineering for Design of Liquid-Propellant Rocket Engines, Progress in Astronautics and Aeronautics, vol. 147, American Institute of Aeronautics and Astronautics, Inc., Washington, DC, 1992, pp. 67-134.

[3] J. Singh, G. Jerman, B. Bhat, R. Poorman, Microstructural Stability Of Wrought, Laser And Electron Beam Glazed NARloy-Z Alloy At Elevated Temperatures, NASA TM-108431, George C. Marshall Space Flight Center, Huntsville, AL, 1993.
[4] H.J. Kasper, in: S.F. Morea, S.T. Wu (Eds.), Advanced High Pressure $\mathrm{O}_{2} / \mathrm{H}_{2}$ Technology, NASA CP 2372, George C. Marshall Space Flight Center, Huntsville, AL, 1985, pp. 36-43.

[5] R.J. Quentmeyer, in: S.F. Morea, S.T. Wu (Eds.), Advanced High Pressure $\mathrm{O}_{2} / \mathrm{H}_{2}$ Technology, NASA CP 2372, George C. Marshall Space Flight Center, Huntsville, AL, 1985, pp. 49-58.

[6] D.B. Morgan, A.C. Kobayashi, Main Combustion Chamber and Cooling Technology Study-Final Report, NASA CR 184345, NASA Marshall Space Flight Center, Huntsville, AL, 1989.

[7] D. Ellis, D. Keller, Thermophysical Properties of GRCop-84, NASA CR 2000210055, NASA Glenn Research Center, Cleveland, OH, 2000.

[8] R. Holmes, D. Ellis, T. McKechnie, Countdown to he Millennium Proceedings, 36th Space Congress, Canaveral Council of Technical Societies, Cape Canaveral, FL, 1999.

[9] R. Hickman, T. McKechnie, R. Holmes, Paper No. AIAA 2001-3693 37th AIAA/ASME/SAE/ASEE/Joint Propulsion Conference, American Institute of Aeronautics and Astronautics, Inc., Salt Lake City, UT, 2001, pp. 1-9.

[10] K.T. Chiang, P.D. Krotz, J.L. Yuen, Surf. Coat. Technol. 76 (1995) 14-19.

[11] K.T. Chiang, J.P. Ampaya, Surf. Coat. Technol. 78 (1996) 243-247.

[12] T.A. Wallace, R.K. Clark, K.T. Chiang, J. Spacecraft Rockets 35 (1998) 546-551.

[13] S. Elam, R. Holmes, T. McKechnie, R. Hickman, T. Pickens, 52nd JANAF Propulsion Meeting/1st Liquid Propulsion Subcommittee Meeting, Las Vegas, Chemical Propulsion Information Agency, The Johns Hopkins University, Baltimore, MD, 2004, pp. 1-10.

[14] S.V. Raj, L.J. Ghosn, C. Robinson, D. Humphrey, Mater. Sci. Eng. A 457 (2007) 300-312.

[15] S.V. Raj, C. Barrett, J. Karthikeyan, R. Garlick, Surf. Coat. Technol. 201 (2007) $7222-7234$.

[16] P.A. Siemers, R.L. Mehan, Mechanical and Physical Properties of Plasma Sprayed Stabilized Zirconia, Report No. 83CRD149, General Electric Company, Schenectady, NY, 1983.

[17] W.J. Brindley, J. Thermal Spray Technol. 6 (1997) 85-90.

[18] L.J. Ghosn, S.V. Raj, Ceramic Eng. Sci. Proc. 23 (2002) 409-416.

[19] S.V. Raj, L.J. Ghosn, A. Agarwal, T.P. Lachtrup, in: S. Seal, N.B. Dahotre, J.J. Moore, C. Suryanarayana, A. Agarwal (Eds.), Surface Engineering: In Materials Science II, The Minerals, Metals \& Materials Society, Warrendale, PA, 2003, pp. 49-56.

[20] Z. Gan, H.W. Ng, A. Devasenapathi, Surf. Coat. Technol. 187 (2004) 307-319.

[21] Y.S. Touloukian, R.K. Kirby, R.E. Taylor, P.D. Desai, Thermal Expansion: Metallic Elements and Alloys, Thermophysical Propertied of Matter, vol. 12, IFI/Plenum, New York, NY, 1975.

[22] T.B. Massalski, H. Okamoto, P.R. Subramanian (Eds.), Binary Alloy Phase Diagrams, ASM International, Materials Park, OH, 1990.

[23] G. Ghosh, in: G. Petzow, G. Effenberg (Eds.), Handbook of Ternary Alloy Phase Diagrams, vol.4, VCH Publishers, New York, NY, 1991, pp. 311-319.

[24] B. Grushko, E. Kowalska-Strzeciwilk, B. Przepiorzynski, M. Surowiec, J. Alloys Compd. 417 (2006) 121-126.

[25] Y.S. Touloukian, Thermophysical Properties of High Temperature Solid Materials. Vol. 6: Intermetallics, Cermets, Polymers and Composite Systems Part I-Intermetallics, The MacMillan Company, New York, NY, 1967.

[26] R.W. Clark, J.D. Whittenberger, in: T.A. Hahn (Ed.), Thermal Expansion, vol.8, Plenum, New York, NY, 1984, pp. 189-196.

[27] T.A. Taylor, P.N. Walsh, Surf. Coat. Technol. 177-178 (2004) 24-31.

[28] S. V. Raj, unpublished research, NASA Glenn Research Center, Cleveland, OH, 2003. 